\title{
Michał Fijałkowski
}

ORCID: 0000-0002-2851-3006

Uniwersytet Opolski

\section{Transfery poselskie w Sejmie III RP jako element strategii politycznej}

DOI: $10.19195 / 1643-0328.26 .4$

Słowa kluczowe: transfery, polski system partyjny, partie parlamentarne, rozłamy

\section{Wprowadzenie}

Problematyka zmiany przynależności partyjnej przez deputowanych legislatur krajowych przez całe dekady była w politologii tratowana marginalnie. W stabilnych demokracjach zakres tego zjawiska nigdy nie był na tyle duży, aby wpływać na stabilność systemu partyjnego, a tym bardziej na stabilność całego systemu politycznego. Występowanie tego zjawiska traktowano trochę jako polityczną anomalię będącą pochodną wybujałych ambicji osobistych, w ujęciu systemowym zaś - niestabilnego układu politycznego ${ }^{1}$. W niektórych systemach — choć kłóciło się to z dosłownie rozumianą wykładnią mandatu wolnego - wprowadzono instytucjonalne ograniczenia lub też rozwiązania mające na celu zniechęcenie potencjalnych „renegatów”2. Niemniej jednak ujawnienie się w latach dziewięćdziesiątych XX wieku w niektórych systemach (Włochy) ${ }^{3}$ zjawiska transferów międzypartyjnych na niespotykaną wcześniej skalę spowodowało podniesienie zainteresowania tą problematyką. Przy tej okazji zwrócono również uwagę, że w innych systemach transfery deputowanych nie są czymś niezwykłym ${ }^{4}$. Kolejnym impul-

1 Zob. szerzej na temat zjawiska Political parties and legislative party switching, red. W.B. Heller, C. Mershon, New York 2009.

${ }^{2}$ K. Janda, Laws against party switching, defecting or floor-crossing in national parliaments, „The Legal Regulation of Political Parties Working Paper" 2009, nr 2, s. 1-23.

3 W.B. Heller, C. Mershon, Party Switching in the Italian Chamber of Deputies 1996-2001, „The Journal of Politics" 67, 2005, nr 2, s. 536-559.

${ }^{4}$ D. Giannetti, K. Benoit, Intra-party politics and coalition governments in parliamentary democracies, [w:] Intra-party politics and coalition governments, red. D. Giannetti, K. Benoit, New York 2009, s. 15. 
sem zwiększającym zainteresowanie transferami było dołączenie - wraz z trzecią falą demokratyzacji - do grona demokracji parlamentarnych dużej grupy państw Europy Środkowo-Wschodniej ${ }^{5}$.

$\mathrm{Na}$ tym tle Polska jawi się jako fenomen. Skala transferów poselskich jest nadzwyczajnie duża i - co ważne - utrzymująca się niezależnie od stopnia konsolidacji systemu partyjnego i samej demokracji. Tym bardziej należy podkreślić, że problematyka ta doczekała się w odniesieniu do Polski marginalnego naświetlenia. Badania na ten temat są dość ogólnikowe i jednocześnie nie oddają istoty zjawiska ${ }^{6}$.

Badania Centrum Badania Opinii Społecznej (CBOS) przeprowadzone pod koniec IV kadencji Sejmu wskazywały, że w opinii społeczeństwa coraz większa liczba posłów reprezentuje jedynie swoje własne interesy, przedkładając je nad interesy społeczeństwa. Była to jednocześnie pierwsza kadencja, w której respondenci tak często wytykali posłom polityczny egoizm ${ }^{7}$. Taką krytyczną społeczną ocenę trudno zweryfikować naukowo. Te same zachowania można bowiem interpretować na kilka sposobów, bez możliwości ich obiektywnej weryfikacji.

Celem niniejszej analizy jest spojrzenie na transfery międzyklubowe w Sejmie z perspektywy racjonalnej strategii politycznej. Należy zaznaczyć, że jest to tylko jedna $\mathrm{z}$ możliwych płaszczyzn eksplanacyjnych tego zjawiska. Pominięcie $\mathrm{w}$ niniejszym opracowaniu innych możliwości wynika z założeń teoretycznych i metodologicznych, a nie z odrzucenia słuszności innych interpretacji.

Zgodnie z przyjętym paradygmatem, za transferem posła - jako racjonalnie działającego aktora politycznego - w trakcie kadencji, kryje się chęć optymalizacji celu, jakim jest zapewnienie sobie reelekcji w kolejnych wyborach.

\section{Teoria i metoda}

Teoretyczną podstawę artykułu stanowią dwie koncepcje: strategia polityczna i struktura możliwości (opportunity structure). W szerszym kontekście kategorie te mieszczą się $\mathrm{w}$ ramach teorii racjonalnego wyboru. Nie odrzucając słabości tego typu podejścia, nie sposób zanegować jego walorów analitycznych ${ }^{8}$.

Pod kątem transferów jako politycznej strategii przebadano okres obejmujący IV-VII kadencje Sejmu, a więc czas od 2001 roku, kiedy to na polskiej scenie partyjnej ukonstytuował się funkcjonujący do dziś układ sił, aż do zakończenia ostatniej pełnej kadencji

${ }^{5}$ R. Ibenskas, A. Sikk, Patterns of Party Change in Central and Eastern Europe, „Cergu's Working Paper Series" 2016, nr 4, s. 2-21.

6 A. Gwiazda, Democracy in Poland. Representation, participation and accountability since 1989, New York 2016, s. 95-113.

7 Parlament w opinii społeczeństwa - podsumowanie kadencji, Komunikat z badań CBOS BS/104/2005, Warszawa 2005, s. 7-8.

8 Zob. Rational Choice Theory. Advocacy and Critique, red. J.S. Coleman, T.J. Fararo, Newbury Park 1992; D.P. Green, I. Shapiro, Pathologies of Rational Choice Theory. A Critique of Applications in Political Science, New Haven 1994. 
parlamentu w 2015 roku. Układ, o którym mowa, to dominacja na scenie politycznej dwóch prawicowych partii o postsolidarnościowym rodowodzie. Dominacja ta w istocie trwa od początku V kadencji Sejmu, kiedy to jedno ze wspomnianych ugrupowań przejęło władzę, jednak to rok ich powstania można uznać za narodziny nowego systemu partyjnego w Polsce. Od tego czasu polski system partyjny ulegał pewnym zmianom pomimo iż nie były one jednak tak fundamentalne jak ta z 2001 roku$^{9}$. Co więcej, to właśnie pierwszej z przebadanych kadencji dotyczą opinie respondentów przytoczone przez CBOS. Można więc uznać ją za kadencję, w której partykularne działania posłów - a więc „racjonalne” z punktu widzenia teorii - zostały dostrzeżone przez wyborców. Joachim Raschke oraz Ralf Tils działania strategiczne definiują jako kalkulację dotyczącą konkretnego czasu, z ujęciem strategicznych, zewnętrznych i merytorycznych czynników ${ }^{10}$. Tę definicję można potraktować tutaj jako punkt wyjścia w kontekście transferów, jednak wartościowym jej uzupełnieniem w sferze nauk politycznych będzie definicja przyjęta przez Dariusza Skrzypińskiego, który strategię polityczną definiuje jako „zbiór zracjonalizowanych decyzji powziętych na podstawie mniej lub bardziej formalnych procedur analitycznych, a dotyczących celów [...] na rynku politycznym"11.

Racjonalność działania - na co zwracają uwagę krytycy teorii racjonalnego wyboru - jest kategorią kontekstualną, zmieniającą się w zależności od konstelacji i uwarunkowań otoczenia. $\mathrm{W}$ ten sposób takie samo lub podobne zachowanie może być racjonalne w jednych warunkach, nieracjonalne zaś w innych. Nie sposób - co zrozumiałe - wziąć pod uwagę całej dynamiki zmian otoczenia. Jednakże sama decyzja o zmianie ugrupowania parlamentarnego jest na ogół podyktowana właśnie zmianą uwarunkowań, zmianą otoczenia, a wraz z nimi zmianą celów postrzeganych jako racjonalne.

Aby uwzględnić ten kluczowy element zmiany, odwołano się do kategorii struktury możliwości. Pojęcie to, wykształcone w socjologii głównie jako płaszczyzna eksplanacyjna nowych ruchów społecznych, może być pewną wskazówką w wyjaśnieniu zjawiska przejść międzyklubowych posłów w trakcie kadencji. Zakłada ono, że działanie jest efektem powstania jego możliwości w danym miejscu i danym czasie ${ }^{12}$. Powstanie ruchów społecznego protestu, które wyjaśniała ta teoria, wiązało się z aktywnościami podjętymi w konkretnych okolicznościach przez określonych aktorów.

Adaptując przyjętą siatkę teoretyczną na rzecz analizy transferów parlamentarnych, badaniu poddano przypadki przejść posłów z partii do partii z uwzględnieniem zarówno tendencji, ulokowania czasowego $\mathrm{w}$ trakcie kadencji, porównania otrzymanych miejsc na listach wyborczych, jak i czynników sprzyjających skuteczności transferów (w kontekście kolejnych wyborów parlamentarnych i potencjalnej reelekcji).

9 A. Antoszewski, System polityczny RP, Warszawa 2012, s. 265-267.

10 C.J. Raschke, R. Tils, Politische Strategie - Eine Grundlage, Wiesbaden 2013, s. 127.

11 D. Skrzypiński, Strategie partii politycznych, [w:] Marketing polityczny w teorii i praktyce, red. A.W. Jabłoński, L. Sobkowiak, Wrocław 2002, s. 140.

12 D.S. Meyer, D.C. Minkoff, Conceptualizing Political Opportunity, „Social Forces” 4, 2004, nr 82, s. 1463. 
Dwie części analizy mają na celu zweryfikowanie dwóch hipotez badawczych:

H1: Transfery parlamentarne są reakcją posłów na spadek notowań partii macierzystej, stają się tym samym racjonalnym działaniem wpisanym w strategię „opuszczania tonącego statku".

H2: Transfery parlamentarne są skuteczną strategią zwiększenia szans reelekcji posłów w kolejnych wyborach parlamentarnych.

W celu zweryfikowania hipotezy pierwszej dokonano dwóch operacji analitycznych. Sprawdzono istnienie korelacji między poparciem społecznym dla danej partii a liczbą jej posłów. Stwierdzenie, że wraz ze spadkiem poparcia maleje liczba członków klubu parlamentarnego, pozwala przyjąć, że posłowie opuszczają partię, gdy notuje ona kryzys poparcia, gdyż tym samym zmniejszają się ich szanse na reelekcje (w kolejnych wyborach wraz z gorszym wynikiem zmniejszy się liczba uzyskanych przez partię mandatów). Opierając się na założeniu wskazanym przez Johna H. Aldricha i Williama T. Bianco, że na występowanie transferów wpływają zmiany poparcia partii politycznych ${ }^{13}$, w artykule przebadano relację liczby mandatów ugrupowań do ich notowań w sondażach. W jej analizie wykorzystano współczynnik autorstwa Karla Pearsona, mierzący korelacje pomiędzy zjawiskami. W przyjętym przez niego założeniu -1 oznacza zupełny brak korelacji, natomiast 1 - całkowitą korelację ${ }^{14}$.

Potwierdzenie korelacji między poparciem wyborczym a liczbą transferów nie daje jednak odpowiedzi, co warunkuje co. Innymi słowy, nie jest jasne, czy posłowie odchodzą z danej partii, bo spada dla niej poparcie, czy też poparcie spada, bo posłowie odchodzą z partii. Aby to zweryfikować, dokonano zestawienia dwóch linii trendu: pierwszej odnoszącej się do poparcia wyborczego dla partii na rok przed największym rozłamem, drugiej odnoszącej się do poparcia dla partii rok po największym rozłamie. Tym sposobem możliwe stanie się określenie, który czynnik jest istotniejszy. Jeśli linia trendu przed rozłamem będzie rosła lub będzie stabilna, ale na wysokim poziomie (stabilizacja mierzona odniesieniem do wyniku uzyskanego w wyborach), będzie to dowodzić, że transfer nie jest spowodowany kryzysem w partii. Nie jest zatem działaniem racjonalnym. Jeśli linia trendu będzie wykazywała tendencję spadkową lub utrzyma się na stabilnym, ale niskim poziomie (stagnacja, mierzona odniesieniem do wyniku uzyskanego w wyborach), będzie to oznaczało, że transfer jest wynikiem kryzysu lub stagnacji w partii. Taki transfer uznamy za działanie racjonalne, a zatem potwierdzone zostanie, że transfer może być elementem strategii politycznej.

Weryfikacja drugiej hipotezy, dokonana w kolejnej części, opiera się na analizie skutków transferów. Sprawdzone zostanie, czy zmiana przynależności klubowej (ewentualnie odejście z klubu) rzeczywiście przyniesie korzyść transferowiczom. Porównano tu dwie kategorie posłów: „transferowiczów” oraz „lojalistów” (pozostający w klubie macierzystym). Jeśli transfery skutkują statystycznie zwiększeniem szans na lepsze miejsce

13 J.H. Aldrich, W.T. Bianco, A Game Theoretic Model of Party Affiliation of Candidates and Office Holders, „Mathematic and Computer Modelling” 16, 1992, nr 8/9, s. 103-115.

14 J. Hauke, T. Kossowski, Comparison of values of Pearson's and Spearman's correlation coefficients on the same sets of data, „Quaestiones Geographicae” 2, 2011, nr 30, s. 88-95. 
wyborcze i/lub reelekcją do Sejmu (dalej: parlamentu), w kolejnych wyborach uznamy, że hipoteza druga została potwierdzona. Jeśli korzystniejsze okaże się pozostanie lojalnym wobec partii macierzystej, uznamy, że falsyfikuje to hipotezę drugą.

\section{Co warunkuje co? Racjonalność transferów parlamentarnych}

Weryfikacja pierwszej z hipotez możliwa będzie dzięki zestawieniu wyników sondażowych CBOS z liczbą posłów w ugrupowaniu dla partii, które uległy największym dekompozycjom w każdej z czterech badanych kadencji.

W IV kadencji Sejmu największy ubytek posłów dotknął rządzący Sojusz Lewicy Demokratycznej (SLD), z którego w marcu 2004 roku wykształciło się nowe ugrupowanie - Socjaldemokracja Polska (SdPl).

Rycina 1. Poparcie dla SLD a liczba posłów (IV kadencja)

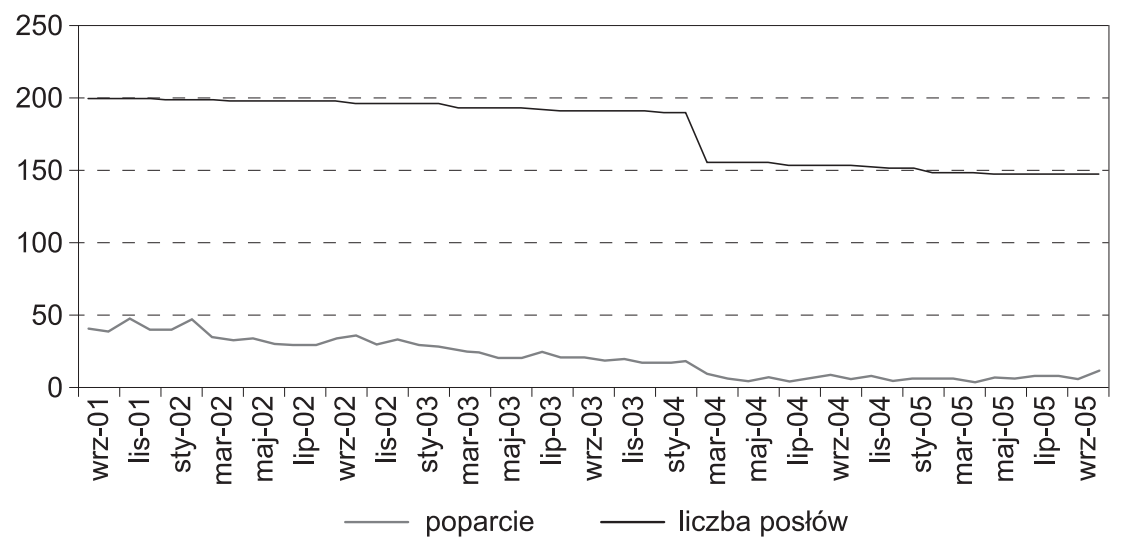

Źródło: opracowanie własne na podstawie www.cbos.pl, www.pkw.gov.pl oraz www.sejm.gov.pl.

Rycina 1 obrazuje dwie wartości: liczbę posłów oraz poparcie dla SLD w ciągu całej IV kadencji Sejmu. Współczynnik korelacji Pearsona w odniesieniu do przedstawionych danych wyniósł 0,90. Wartość ta lokuje się bardzo blisko 1 oznaczającej całkowitą korelację danych. Potwierdza to przytoczoną tezę Johna H. Aldricha i Williama T. Bianco o silnej relacji między transferami a poparciem dla partii politycznych. Przypadek SLD i rozłamu w postaci SdPl wygląda tu na elementarny. Wyliczony współczynnik bezpośrednio wskazuje, że korelacja pomiędzy spadającym poparciem dla SLD a rozłamem jest niezaprzeczalna. Pełne zweryfikowanie pierwszej założonej hipotezy będzie możliwe jednak dopiero po zwróceniu uwagi na trend sondażowy przed i po rozłamie.

Już na wstępie można zauważyć, że rok przed odejściem grupy posłów poparcie dla SLD odbiegało od wyniku wyborczego o ponad 15 punktów procentowych. W ciągu dwunastu miesięcy przed feralnym dla SLD marcem 2004 roku można było zaobserwować konsekwentny spadek poparcia partii rządzącej. Można zatem przyjąć, że działanie posłów opuszczających SLD miało znamiona racjonalnej strategii. 


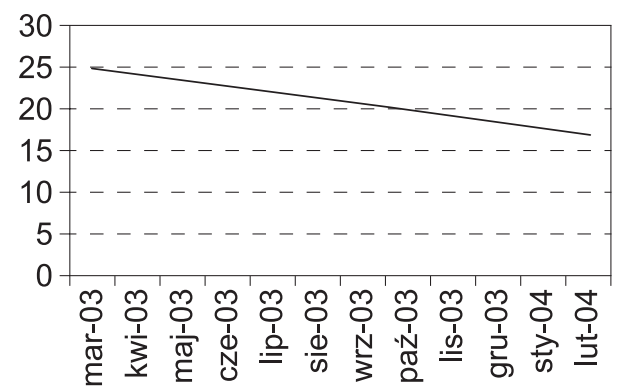

Rycina 2a. Poparcie dla SLD w roku poprzedzającym rozłam i utworzenie SdPl — linia trendu

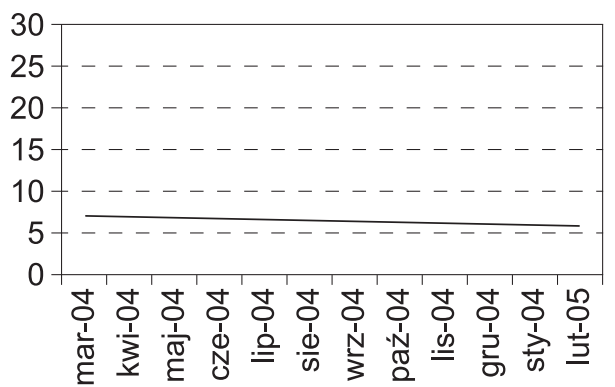

Rycina 2b. Poparcie dla SLD w roku następującym po rozłamie i utworzeniu $\mathrm{SdPl}$ - linia trendu

Źródło: opracowanie własne na podstawie Biuletynów CBOS z lat 2001-2005, www.cbos.pl.

Rycina $2 \mathrm{~b}$ pokazuje, że notowania partii po rozłamie wciąż ulegały trendowi spadkowemu, jednak nie tak drastycznemu, jak w okresie między marcem 2003 a marcem 2004 roku. Należy jednak zauważyć, że w przypadku dekompozycji SLD w IV kadencji mamy do czynienia z pewnym interesującym zjawiskiem — spadek poparcia doprowadził $w$ tej formacji do rozłamu, a jego nastąpienie pogłębiło sondażową degradację ugrupowania.

W skróconej V kadencji Sejmu największy ubytek liczby posłów dotknął Samoobrony RP (Samoobrony). W wyniku perturbacji związanych $\mathrm{z}$ udziałem partii w koalicji rządzącej z ugrupowania wyłonił się nowy klub - Ruch Ludowo-Narodowy (RLN).

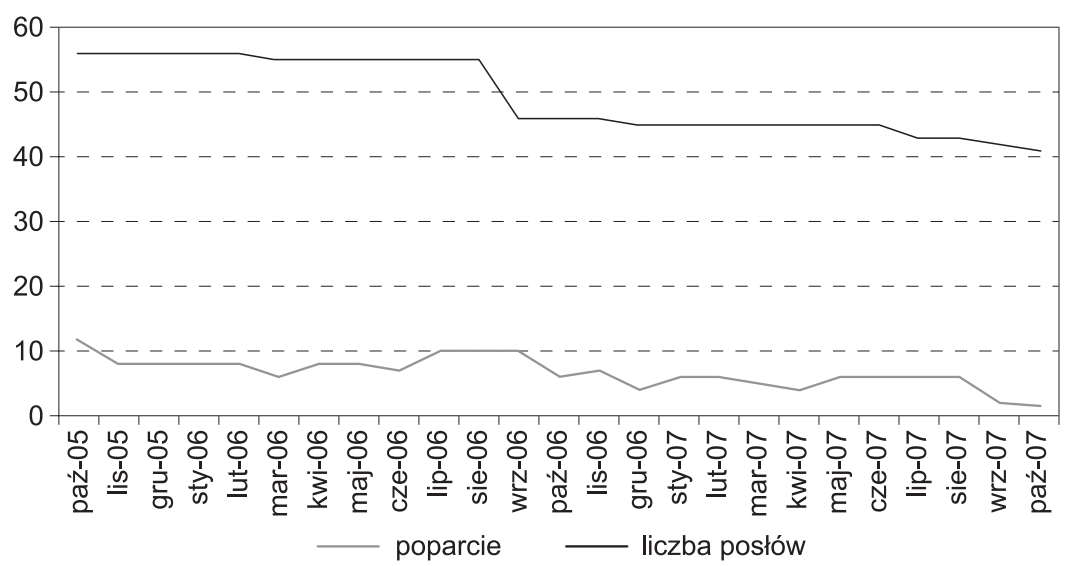

Rycina 3. Poparcie dla Samoobrony RP a liczba posłów (V kadencja)

Źródło: opracowanie własne na podstawie www.pkw.gov.pl, www.sejm.gov.pl oraz www.cbos.pl.

Obliczenia dla zestawionych z sobą wartości znów dają obiecujące rezultaty. Wskaźnik korelacji tych danych, wyliczony dla Samoobrony RP w ciągu dwuletniej V kadencji, wyniósł 0,72 . Kolejny raz mamy więc do czynienia z silną relacją pomiędzy zachowaniami posłów a poparciem dla partii macierzystej. 
Po zobrazowaniu w formie linii trendu poparcia dla Samoobrony RP na rok przed największym odpływem posłów do nowo powstałego klubu Ruchu Ludowo-Narodowego można zaobserwować nieco odmienne zjawisko niż w przypadku SLD. Samoobrona, która w 2005 roku uzyskała w wyborach ponad 11\% głosów wyborców, nie uległa tak znaczącemu spadkowi poparcia, jak SLD. Wyniki sondażowe przyniosły jednak stagnację - względnie stabilny wynik sondażowy, jednak poniżej oczekiwań i osiągniętego $\mathrm{w}$ wyborach pułapu. Posłowie Samoobrony również mogli uznać to za sygnał, że partia nie ma potencjału na kolejne wybory, dokonując rozłamu we wrześniu 2006 roku.

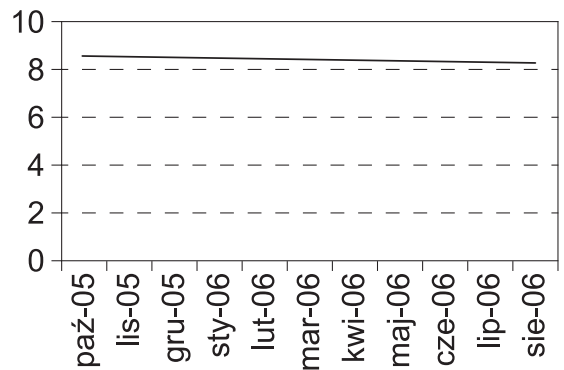

Rycina 4a. Poparcie dla Samoobrony RP $\mathrm{w}$ roku poprzedzającym rozłam i utworzenie RLN — linia trendu

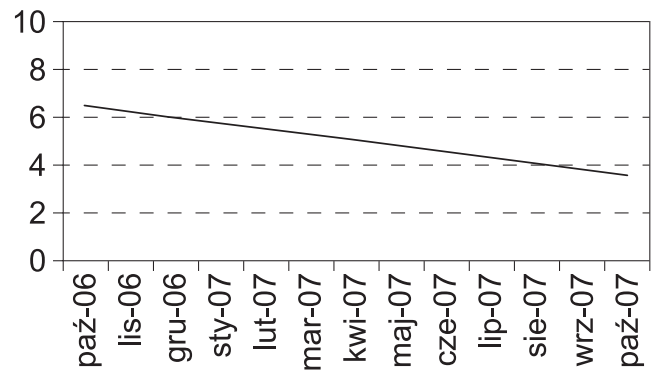

Rycina 4b. Poparcie dla Samoobrony RP w roku następującym po rozłamie i utworzeniu RLN - linia trendu

Źródło: opracowanie własne na podstawie Biuletynów CBOS z lat 2005-2007, www.cbos.pl.

Rycina $4 \mathrm{~b}$ obrazująca trend sondażowy Samoobrony po powstaniu RLN pokazuje już jednak analogiczne zjawisko do zaobserwowanego w IV kadencji. Rozłam jest dla partii tąpnięciem, od którego zaczyna się już wyraźny spadek sondażowy - nawet jeśli wcześniejsza degradacja poparcia nie była aż tak wyraźna, jak w przypadku SLD. Przedstawione dane nasuwają więc podobne wnioski, co w IV kadencji — rozłam w Samoobronie był silnie skorelowany z poparciem dla ugrupowania, a badanie trendów sugeruje, że posłowie działali według racjonalnej strategii.

W VI kadencji Sejmu najliczniejszy ubytek stanu posiadania dotknął największe ugrupowanie opozycyjne - Prawo i Sprawiedliwość (PiS), którego liberalne skrzydło utworzyło własne ugrupowanie o nazwie Polska Jest Najważniejsza (PJN).

Zestawienie poparcia dla tego ugrupowania z liczbą mandatów w klubie prowokuje do nieco głębszej analizy. Wskaźnik Pearsona obliczony dla ugrupowania, które w latach 2007-2011 uległo największej dekompozycji, wyniósł 0,03. Wynik ten lokuje się niemal dokładnie na środku wspomnianego zakresu, co zmusza obserwatora do nieco większej refleksji nad powstaniem PJN. Należy zauważyć, iż uwarunkowania tego rozłamu były zgoła inne, aniżeli dwóch wspomnianych. Pomimo iż dokonał się on w jednym $\mathrm{z}$ większych ugrupowań parlamentarnych, jego źródła były pozaparlamentarne - dyskusja nad strategią obraną w przegranych przez Jarosława Kaczyńskiego wyborach prezydenckich doprowadziła do odejścia centrowego skrzydła PiS będącego trzonem wspomnianej kampanii. Na odejście nie miały więc wpływu sondaże, lecz spór nad strategią i przegrane przez partię wybory prezydenckie, w czasie których, co ciekawe, notowania partii były jednymi z wyższych w ciągu tamtej kadencji. 


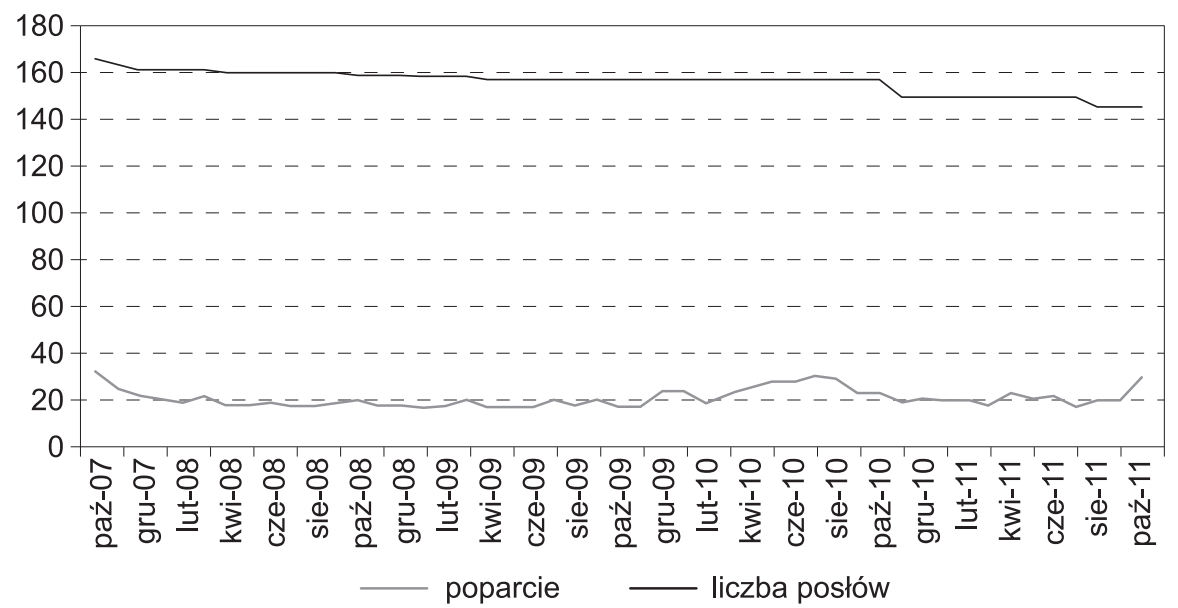

Rycina 5. Poparcie dla PiS a liczba posłów (VI kadencja)

Źródło: opracowanie własne na podstawie www.pkw.gov.pl, www.sejm.gov.pl oraz www.cbos.pl.

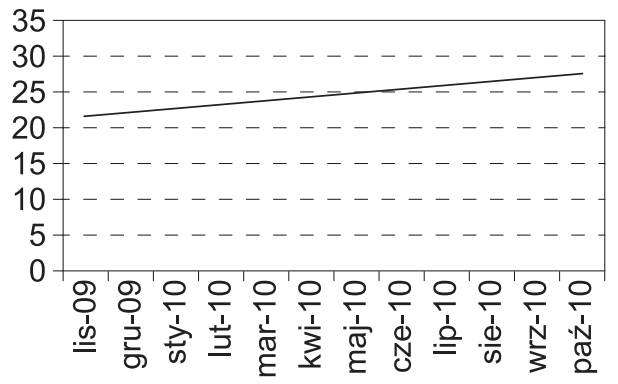

Rycina 6a. Poparcie dla PIS w roku poprzedzającym rozłam i utworzenie PJN - linia trendu

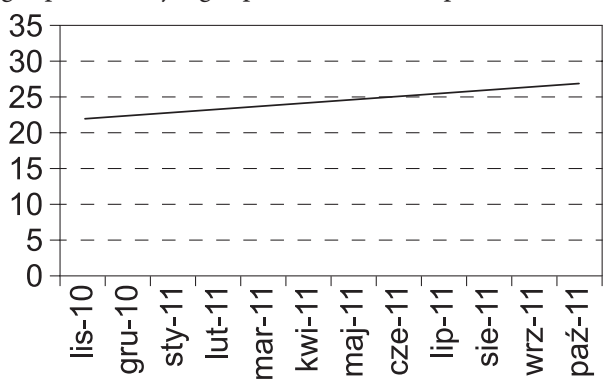

Rycina 6b. Poparcie dla PiS w roku następującym po rozłamie i utworzeniu PJN — linia trendu

Źródło: opracowanie własne na podstawie Biuletynów CBOS z lat 2007-2011, www.cbos.pl.

Rycina 6a potwierdza sformułowaną wcześniej tezę, że PiS w ciągu poprzedzającego roku cieszył się stałym wzrostem poparcia. Wyniki sondażowe nie mogły więc leżeć u źródeł decyzji posłów o rozstaniu się z partią. Nieodłączne wiązanie transferów posłów z poparciem dla partii politycznych byłoby oczywiście założeniem dość naiwnym, co przykład PiS i jego dekompozycji zdaje się potwierdzać. Ulokowanie czasowe powstania PJN na linii trendu poparcia PiS pokazuje, że rozłam ten miał charakter bardziej ideowy, będący wynikiem sporu o strategię wewnątrz partii, nie był zaś skutkiem strategicznej kalkulacji posłów.

Unikalność tego przypadku potwierdza również linia trendu poparcia po odejściu posłów do PJN. Brak tu charakterystycznego tąpnięcia, jakiego doświadczono zarówno w SLD, jak i w Samoobronie po secesji.

Ostatnim z badanych przypadków jest Ruch Palikota/Twój Ruch (RP/TR), formacja, w której z czterdziestu posłów wybranych z jej list do Sejmu w kole poselskim na końcu VII kadencji pozostało jedynie trzynastu. 


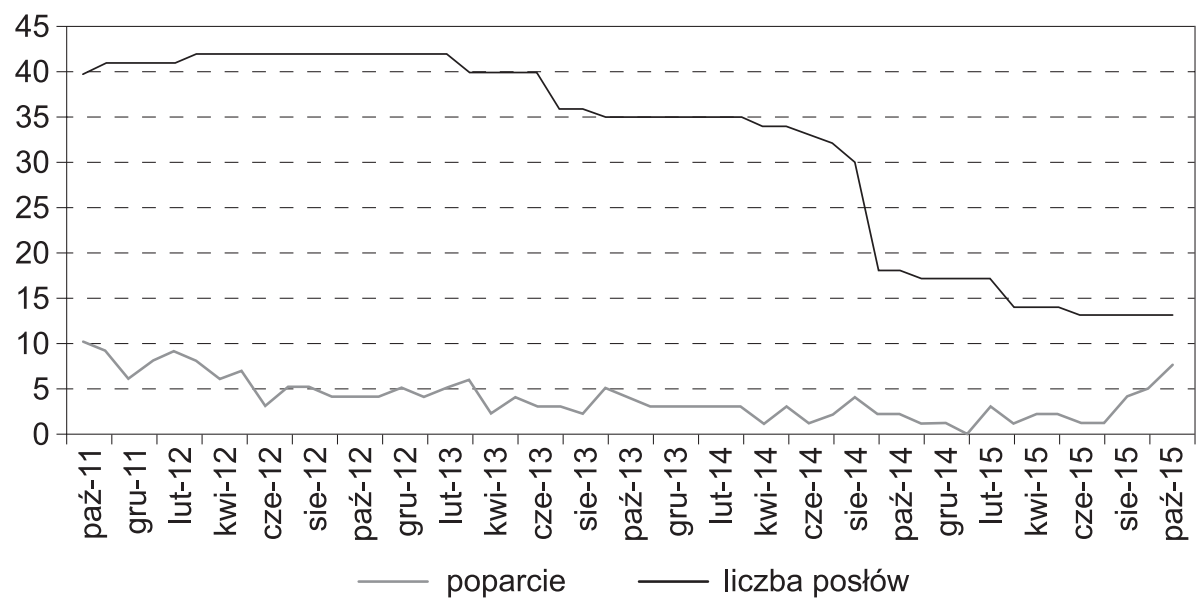

Rycina 7. Poparcie dla RP/TR a liczba posłów ugrupowania

Źródło: opracowanie własne na podstawie www.pkw.gov.pl, www.sejm.gov.pl oraz www.cbos.pl.

Dla ugrupowania, z którego w ciągu kadencji uciekło aż trzy czwarte posłów, wskaźnik korelacji Pearsona wyniósł 0,50. To oznacza, że można mówić o względnej korelacji poparcia $\mathrm{z}$ „wędrówkami” posłów. RP po początkowym wzroście stanu posiadania $\mathrm{w}$ drugiej kadencji regularnie tracił swoich posłów na rzecz innych ugrupowań, podobnie było z poparciem. Po wyniku wyborczym sięgającym $10 \%$ w kolejnych miesiącach partia balansowała na granicy progu wyborczego, by go ostatecznie nie sforsować nawet pomimo mariażu z SLD (którego wyższy wynik sondażowy jest wyraźnie widoczny przy końcu kadencji). Waldemar Wojtasik wskazuje, że u źródeł powstania RP również leżało przytoczone na początku tego tekstu opportunity structure. Być może jest to uzasadnieniem szybkiej dekompozycji partii, która skuteczna była jedynie w okresie kampanii wyborczej w 2011 roku, a w późniejszym czasie bezskutecznie szukała w parlamencie pomysłu na kolejny sukces wyborczy ${ }^{15}$.

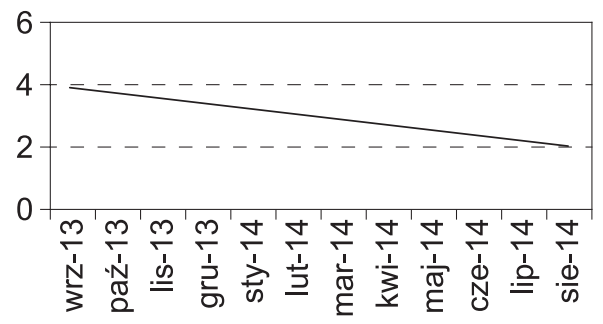

Rycina 8a. Poparcie dla RP/TR w roku poprzedzającym największy odpływ posłów - linia trendu

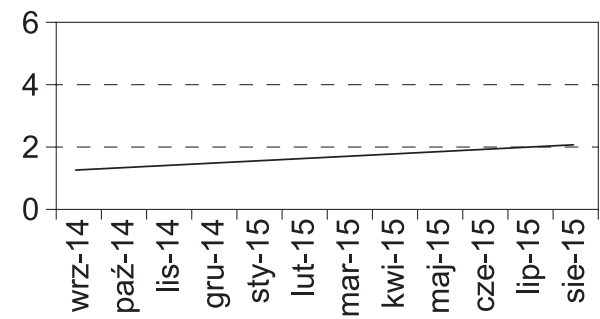

Rycina 8b. Poparcie dla RP/TR w roku następującym po największym odpływie posłów — linia trendu

Źródło: opracowanie własne na podstawie Biuletynów CBOS z lat 2011-2015, www.cbos.pl.

15 W. Wojtasik, Sukces Ruchu Palikota w świetle czynników możliwego sukcesu politycznego (Political Opportunity Structure), „Preferencje Polityczne” 2012, nr 3, s. 159-174. 
Przypadek rozpadu RP jest analogiczny do SLD w IV kadencji oraz Samoobrony w V kadencji. Systematyczny spadek parcia ukazuje przesłanki, jakimi mogli kierować się posłowie centrolewicowej formacji właściwie na każdym etapie czteroletniej kadencji, z wyjątkiem pierwszych kilku miesięcy po wyborach.

Również poparcie po największym exodusie posłów RP ujawnia analogie z poprzednimi kadencjami. Rozłam, u którego podstaw leżą słabe sondaże, wpływa na spójność partii, siłę przekazu, a w efekcie doprowadza do stabilizacji poparcia na niskim poziomie. RP/TR jawi się tu jako książkowy przykład, pomimo iż w wyniku odejść posłów nie powstała żadna nowa partia. Jedynym ugrupowaniem skupiającym byłych posłów RP/TR było funkcjonujące przez kilka miesięcy koło Bezpieczeństwo i Gospodarka.

Analiza czterech największych rozłamów partyjnych w latach 2001-2015 pozwala stwierdzić, że w większości przypadków za opuszczeniem ugrupowania macierzystego kryje się chęć "utrzymania się na powierzchni” sceny politycznej. Tylko jedno z analizowanych ugrupowań nie przejawiało cech „tonącego okrętu”, co wskazuje na unikalność przypadku, nie neguje natomiast zaobserwowanej prawidłowości.

\section{Korzyści płynące z transferów w kontekście reelekcji}

Właściwa analiza transferów w poszczególnych kadencjach Sejmu możliwa jest, gdy weźmie się pod uwagę skalę zjawiska w Polsce. Jest ona wyraźnie większa niż w tak zwanych starych demokracjach, jak Niemcy, Norwegia czy Szwecja. W tych państwach transfery są zjawiskiem incydentalnym czy wręcz marginalnym.

Tabela 1. Liczba transferów w ugrupowaniach parlamentarnych w latach 2001-2015

\begin{tabular}{l|c|c|c}
\hline Kadencja Sejmu & $\begin{array}{c}\text { Liczba posłów } \\
\text { przechodzących } \\
\text { (party switchers) }\end{array}$ & $\begin{array}{c}\text { Liczba transferów } \\
\text { (PPS - parliamentary } \\
\text { party switches) }\end{array}$ & $\begin{array}{c}\text { Procent całości } \\
(460=100 \%)\end{array}$ \\
\hline IV (2001-2005) & 118 & 149 & 25,65 \\
\hline V (2005-2007) & 33 & 48 & 7,17 \\
\hline VI (2007-2011) & 40 & 58 & 8,70 \\
\hline VII (2011-2015) & 69 & 101 & 15 \\
\hline
\end{tabular}

Źródło: opracowanie własne na podstawie www.pkw.gov.pl oraz www.sejm.gov.pl.

Pierwsza $\mathrm{z}$ badanych kadencji była w Polsce rekordowa pod względem liczby przypadków. Ponadto należy zauważyć, że w latach 2005-2011 mieliśmy do czynienia ze znacznie mniejszą skalą zjawiska aniżeli w IV kadencji. Można przypuszczać, że ten stan rzeczy spowodowany był ustabilizowaniem się systemu partyjnego, z dominacją dwóch centroprawicowych partii. Szczegółowa analiza zjawiska z uwzględnieniem czynników jakościowych wymaga jednak wnikliwego badania każdej z kadencji. 


\section{IV kadencja Sejmu (2001-2005)}

Jak już wspomniano, wybory w 2001 roku mogą stanowić symboliczną datę początku istniejącego obecnie układu sił na polskiej scenie politycznej. Pomimo że formacją zwycięską w ówczesnej kampanii był Sojusz Lewicy Demokratycznej (SLD), który w 2015 roku znalazł się poza parlamentem (utrzymując jednak status ugrupowania relewantnego), to właśnie wtedy swoich przedstawicieli do Sejmu pierwszy raz wprowadziły Platforma Obywatelska (PO) oraz Prawo i Sprawiedliwość (PiS). Kadencja IV była również rekordowa pod względem liczby transferów międzypartyjnych. Wynikało to przede wszystkim z analizowanej już dekompozycji SLD, której partia uległa wskutek powstania Socjaldemokracji Polskiej (SdPl). Członkostwo w tym nowo powstałym ugrupowaniu było najczęściej wybieranym rozwiązaniem przez „uciekających” z obarczonego ciężarem afer politycznych Sojuszu.

Jak pokazuje tabela 2, porzucenie SLD okazało się nietrafione w kontekście potencjalnej reelekcji. Żaden z posłów opuszczających największą formację IV kadencji nie uzyskał reelekcji w wyborach w 2005 roku, mimo że aż dwudziestu sześciu z trzydziestu jeden posłów znalazło się na listach wyborczych wyżej niż w ugrupowaniu macierzystym. Pozycje na listach przestają jednak mieć znaczenie, gdy formacja nie przekracza granicy progu wyborczego.

Ogółem w całej kadencji jedynie czterech posłów zmieniających ugrupowanie uzyskało mandat. $Z$ wymienionych $w$ tabeli 2 ugrupowań byli to posłowie PSL, PiS, Samoobrony RP oraz UP. Można zauważyć, że bardziej opłacalnym działaniem w kontekście reelekcji było pozostanie w partii macierzystej. Ta prawidłowość dotyczy każdej z wymienionej w tabeli partii, a ukazana procentowa skuteczność strategii jednoznacznie wskazuje na korzyść „lojalistów”.

\section{V kadencja Sejmu (2005-2007)}

W V kadencji Sejmu, przypadającej na lata 2005-2007, doszło do spadku liczby przypadków zmian przynależności klubowej. Mogło to wynikać zarówno ze stabilizacji na scenie politycznej ${ }^{16}$ (w Sejmie nie zameldowała się żadna nowa partia polityczna), jak i z kwestii skrócenia kadencji w 2007 roku.

Należy zauważyć, że mimo mniejszej liczby przejść w partiach parlamentarnych okazały się one skuteczniejsze. Jedynie posłowie Samoobrony w komplecie „polegli” $\mathrm{w}$ procesie wyborczym. Tym razem przynajmniej w połowie przypadków skuteczne okazały się transfery posłów LPR i PO. Warto zauważyć, że żaden z ponownie wybranych byłych posłów LPR nie otrzymał lepszego miejsca na listach wyborczych niż w poprzedniej kampanii. Do Sejmu wybrano również jednego posła, który w trakcie

16 K. Zuba, Polska scena polityczna. Ciagłość i zmiana, Warszawa 2012, s. 224-225. 
kadencji opuścił klub PiS. To jednak przypadek LPR pokazuje, że obrana przez posłów strategia przetrwania może się okazać skuteczna. V kadencja Sejmu była ostatnią, w której partia ta sforsowała próg wyborczy, jednak trzech posłów LPR skutecznie odnalazło swoją szalupę ratunkową - listy wyborcze PiS ${ }^{17}$.

Klub Samoobrony, którego zarówno transferujący posłowie, jak i ci pozostali w klubie nie uzyskali reelekcji, był formacją, która w V kadencji uległa najistotniejszej dekompozycji. W odnalezieniu przyczyn tej sytuacji może pomóc zestawienie stanu posiadania klubu z notowanym przez partię poparciem $\mathrm{w}$ trakcie kadencji.

\section{VI kadencja Sejmu (2007-2011)}

Niewielki wzrost liczby transferów przyniosła kolejna kadencja Sejmu. Pomimo iż była ona dwa razy dłuższa od skróconej V kadencji, odnotowano jedynie siedem przypadków transferów więcej. Najwięcej posłów zdecydowało się opuścić Prawo i Sprawiedliwość partię, która w 2007 roku utraciła władzę i stała się największym ugrupowaniem opozycyjnym VI kadencji.

Wobec uznania transferu poselskiego za potencjalną drogę do uzyskania reelekcji w VI kadencji posłom nieszczególnie opłacało się wybrać tę drogę do pozostania na urzędzie. Posłowie opuszczający PO w większości nie zdecydowali się na ponowny start w wyborach do Sejmu. Nieskuteczną próbę uzyskania reelekcji podjął jeden deputowany. Skuteczność strategii posłów PiS i SLD była zbliżona i plasowała się na poziomie kilkunastu procent. Warto jednak zauważyć, że ponad połowa $\mathrm{z}$ walczących o reelekcję posłów PiS uzyskała lepsze miejsca na listach niż w partii macierzystej przy okazji poprzednich wyborów.

\section{VII kadencja Sejmu (2011-2015)}

VII kadencja Sejmu przyniosła nasilenie skali zjawiska przejść posłów. W największym stopniu wynikało ono ze znaczącej dekompozycji nowego ugrupowania w parlamencie - Ruchu Palikota (RP). Po początkowym powiększeniu stanu posiadania klub uległ niemal całkowitemu rozpadowi, pod koniec kadencji funkcjonując już jedynie jako koło poselskie $^{18}$. Duża liczba posłów opuściła też PiS, głównie za sprawą rozłamu w postaci Solidarnej Polski (SP). Co ciekawe, SP w kolejnych wyborach i tak trafiła na listy PiS, dokonując swoistej rewizji strategii politycznej ${ }^{19}$.

17 Wybory 2005, PKW, Warszawa 2005, http://wybory2005.pkw.gov.pl/SJM/PL/WYN/W/index.htm (dostęp: 20.06.2018).

18 S. Klauziński, Gdzie poszli ludzie Palikota, „Gazeta Wyborcza” 23.03.2015, s. 6.

19 E. Cichocka, Kaczyński: Witamy nowy namiot w obozie, „Gazeta Wyborcza” 27.04.2015, s. 9. 


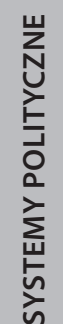

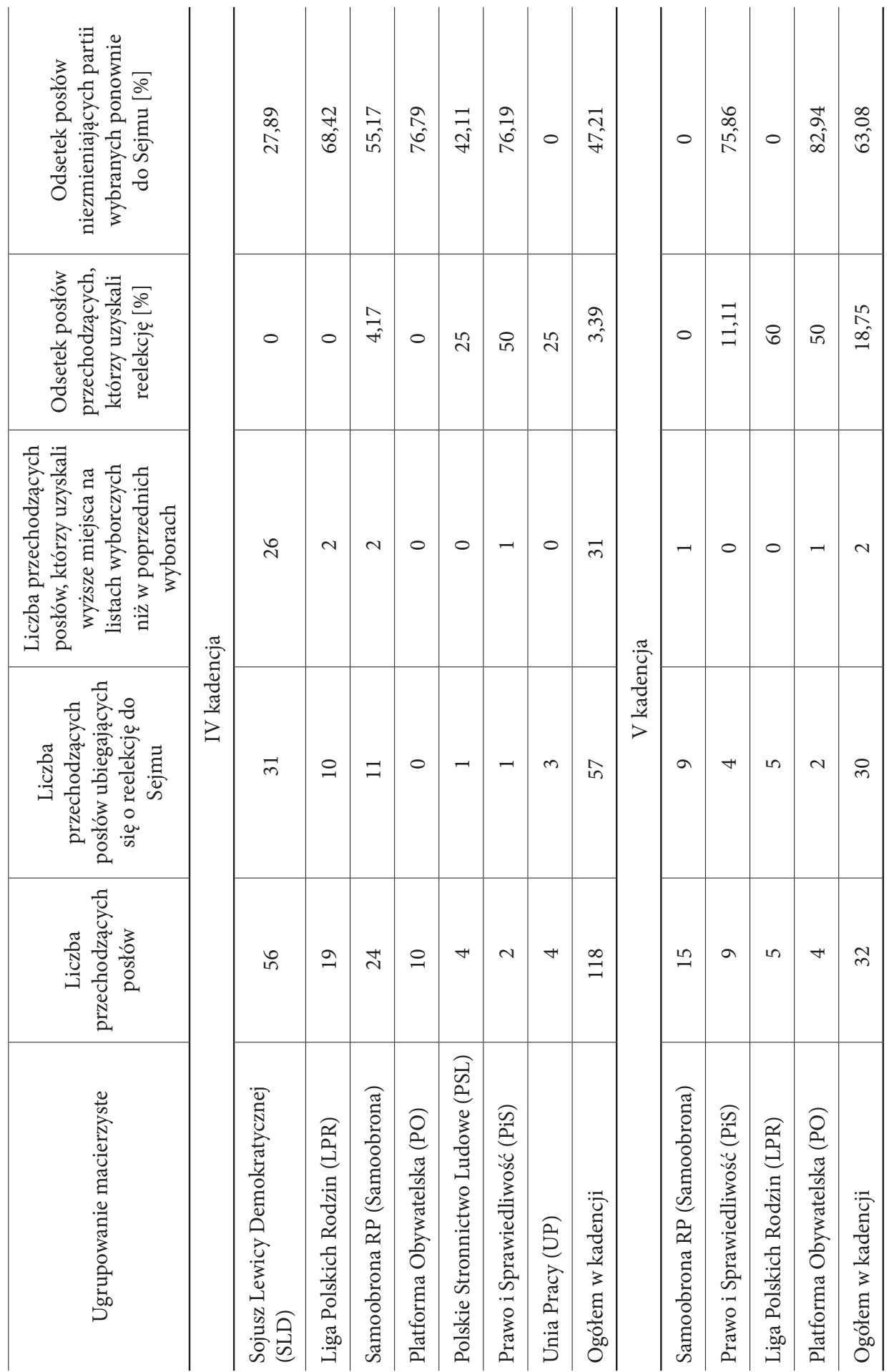




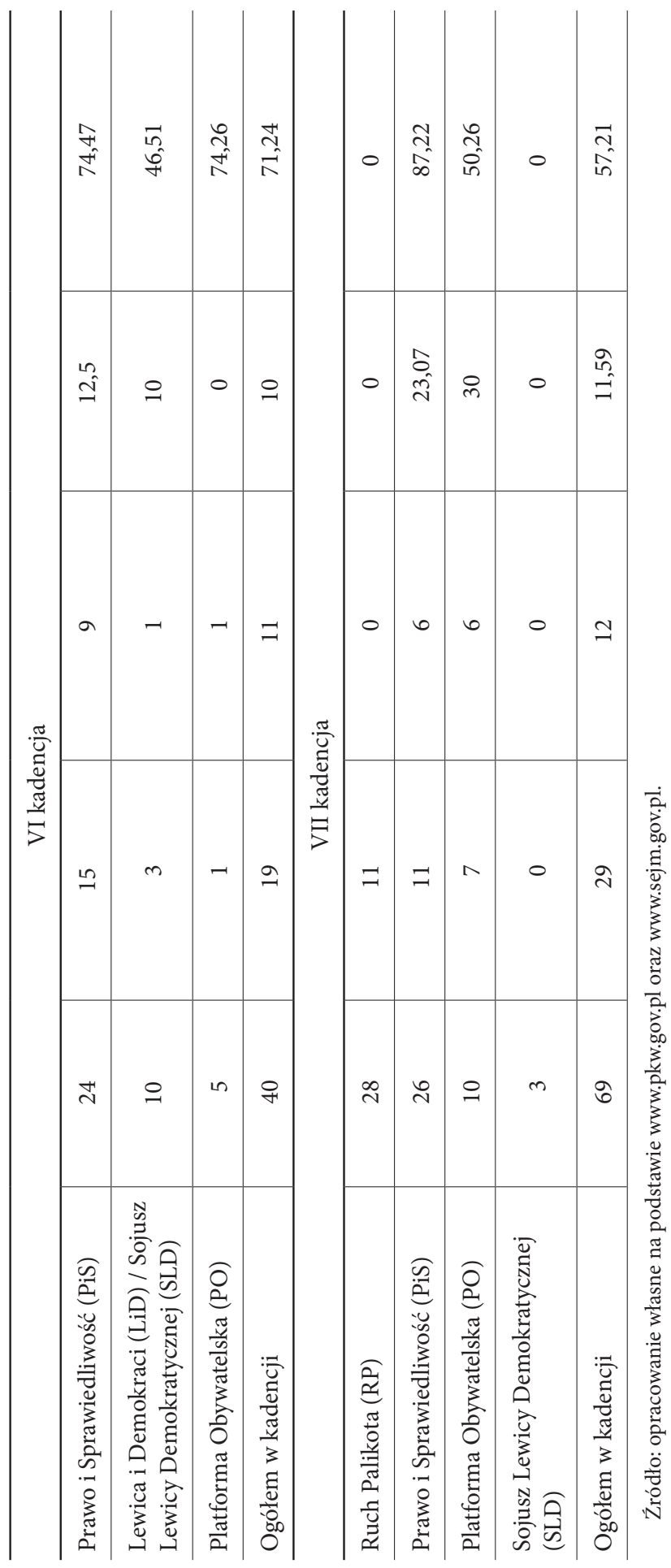


Jak pokazują przedstawione dane, mimo że to właśnie spadek notowań partii skłonił posłów RP do zmiany przynależności klubowej, nie byli oni w stanie odnaleźć skutecznego sposobu na ponowny wybór do Sejmu $-\mathrm{z}$ parlamentem pożegnali się zarówno transferowicze, jak również lojalni posłowie.

Wspomniani rozłamowcy z PiS byli tym razem skuteczniejsi, aż jedna piąta z nich ponownie znalazła się w parlamencie. Co więcej, większość z ubiegających się o reelekcję uzyskała również lepsze miejsca na listach wyborczych niż w 2011 roku (choć ponownie znajdując się na listach tego samego ugrupowania - w tym wypadku transfer okazał się skuteczną kartą przetargową). Zbliżoną skuteczność miały ruchy byłych posłów PO, a los RP podzielił jego wyborczy sojusznik - SLD, którego startujących w wyborach rozłamowców zabrakło, aczkolwiek sam Sojusz nie sforsował progu wyborczego dla koalicji.

\section{Podsumowanie}

Przytoczone w głównej części artykułu dane potwierdzają hipotezę, że transfery posłów $\mathrm{w}$ ugrupowaniach parlamentarnych są elementem specyficznej strategii mającej na celu „utrzymanie się na powierzchni” przestrzeni politycznej. Istotna korelacja aż trzech z czterech największych przebadanych rozłamów w latach 2001-2015 ten fakt jedynie potwierdza. Równie ważnym elementem tego typu analizy jest ulokowanie czasowe wszystkich przejść w parlamencie. W tym celu wzięto pod uwagę ogólną liczbę transferów (party switches), biorąc pod uwagę, że poseł zmieniający ugrupowanie, będąc niezadowolonym ze swojej pozycji w partii, mógł być skłonny do ponownego transferu.

Tabela 3. Transfery (PPS) z ulokowaniem czasowym w kadencji

\begin{tabular}{l|c|c|c|c|c}
\hline \multicolumn{1}{c|}{ Kadencja } & $\begin{array}{c}\text { Liczba } \\
\text { transferów } \\
\text { (PPS) }\end{array}$ & $\begin{array}{c}\text { Liczba PPS } \\
\text { w I kwarcie } \\
\text { kadencji }\end{array}$ & $\begin{array}{c}\text { Liczba PPS } \\
\text { w II kwarcie } \\
\text { kadencji }\end{array}$ & $\begin{array}{c}\text { Liczba PPS } \\
\text { w III kwarcie } \\
\text { kadencji }\end{array}$ & $\begin{array}{c}\text { Liczba PPS } \\
\text { w IV kwarcie } \\
\text { kadencji }\end{array}$ \\
\hline IV (2001-2005) & 149 & 23 & 37 & 60 & 28 \\
\hline VI (2007-2011) & 58 & 14 & 6 & 8 & 30 \\
\hline VII (2011-2015) & 101 & 19 & 15 & 34 & 33 \\
\hline
\end{tabular}

Źródło: opracowanie własne na podstawie www.pkw.gov.pl oraz www.sejm.gov.pl oraz biblioteka.sejm.gov.pl.

$\mathrm{W}$ tabeli 3 pominięto $\mathrm{V}$ kadencję, która ze względu na przyspieszone wybory nie jest dostatecznie reprezentatywna, jak kadencje IV, VI oraz VII. Dane zaprezentowane w tabeli ukazują, że istotne nasilenie zjawiska następuje w III oraz IV kwarcie każdej z tych kadencji. Jest to bezpośrednie potwierdzenie tezy, że dla większości polityków zmieniających partie najistotniejszym punktem odniesienia są wybory. Dlatego to właśnie najczęściej w drugiej połowie kadencji posłowie skłonni są do ryzykownych, nerwowych ruchów, mających zapewnić im reelekcję. 


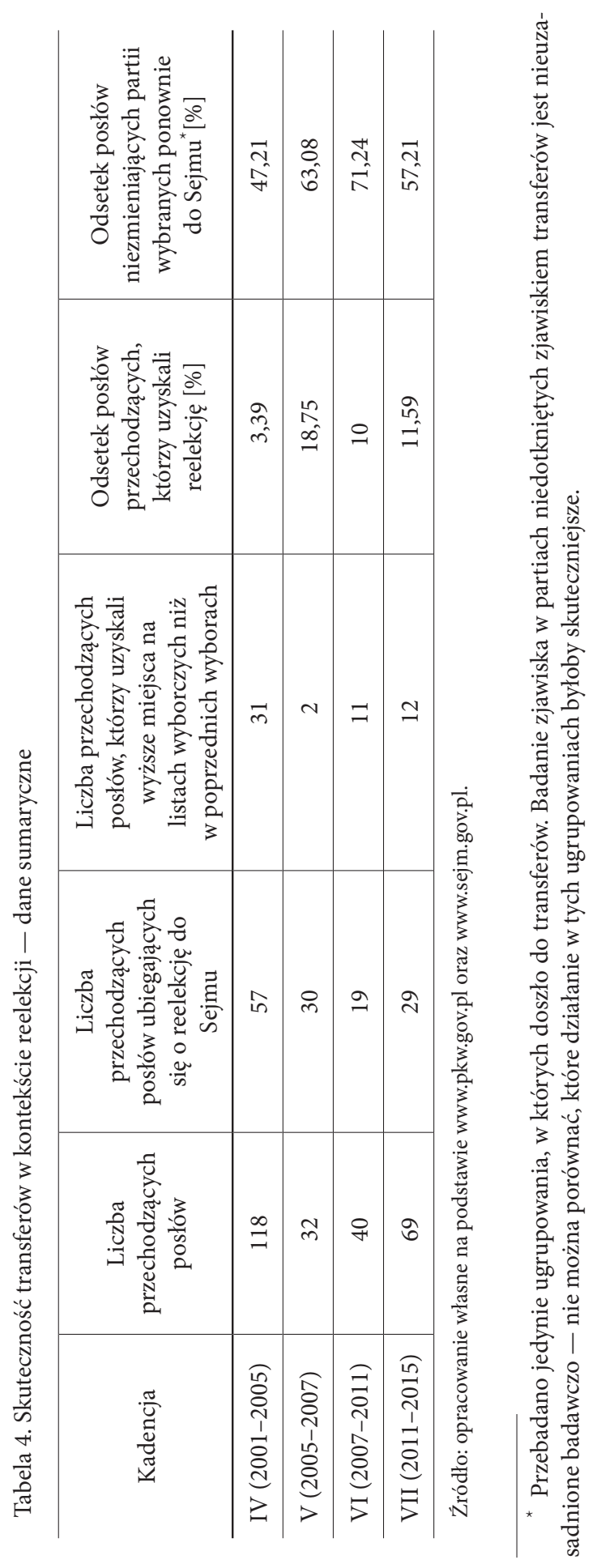


Inna sprawa, że wobec analizy przytoczonych $\mathrm{w}$ artykule danych należy stwierdzić, iż transfer z partii do partii jako strategia mająca doprowadzić do reelekcji jest kompletnie nieuzasadniony. Dane sumaryczne zobrazowane w tabeli 4 uwypuklają ten fakt oraz obrazują negatywną weryfikację drugiej z przyjętych hipotez.

W każdej z przebadanych kadencji wyraźnie większe (nawet kilkakrotnie) szanse na reelekcję miał poseł lojalny wobec swojej partii macierzystej. Jedynie raz - w V kadencji Sejmu — strategia posłów okazała się skuteczniejsza niż partii macierzystej. Odchodzący z LPR posłowie uzyskali reelekcję $\mathrm{w}$ przeciwieństwie do swojego byłego ugrupowania. W pozostałych przypadkach próby odnalezienia szans na ponowny wybór były co najwyżej równie nieskuteczne, co próby wyborcze degradujących się partii. Jedynie pięćdziesięciu sześciu ze stu trzydziestu jeden transferowiczów, co stanowi niemal 43\%, było w stanie uzyskać w swoich nowych ugrupowaniach wyższe miejsca na listach niż w poprzednich wyborach. To również nie sprzyja zasadności transferów.

Porównując przytoczone w artykule kadencje i ugrupowania, należy zauważyć, że wśród parlamentarzystów funkcjonują trzy zasadnicze czynniki racjonalizacji transferów: kryzys partii rządzących (SLD), funkcjonowanie partii w opozycji (PiS, Samoobrona, RP) oraz wyraźny spadek notowań (SLD, RP). Unikatowość przypadku PJN pokazuje jedynie, że kwestia niestabilności personalnej parlamentu jest wielopłaszczyznowa i niejednoznaczna.

\section{Bibliografia}

Aldrich J.H., Bianco W.T., A Game Theoretic Model of Party Affiliation of Candidates and Office Holders, „Mathematic and Computer Modelling” 16, 1992, nr 8/9.

Antoszewski A., System polityczny RP, PWN, Warszawa 2012.

Biblioteka Sejmowa, http://biblioteka.sejm.gov.pl (dostęp: 31.07.2018).

Centrum Badań Opinii Społecznych, www.cbos.pl (dostęp: 31.07.2018).

Cichocka E., Kaczyński: Witamy nowy namiot w obozie, „Gazeta Wyborcza” 27.04.2015.

Giannetti D., Benoit K., Intra-party politics and coalition governments in parliamentary democracies, [w:] Intra-party politics and coalition governments, red. D. Giannetti, K. Benoit, New York 2009.

Green D.P., Shapiro I., Pathologies of Rational Choice Theory. A Critique of Applications in Political Science, Yale University Press, New Haven 1994.

Gwiazda A., Democracy in Poland. Representation, participation and accountability since 1989, Routledge, New York 2016.

Hauke J., Kossowski T., Comparison of values of Pearson's and Spearman's correlation coefficients on the same sets of data, „Quaestiones Geographicae” 2, 2011, nr 30.

Heller W.B., Mershon C., Party Switching in the Italian Chamber of Deputies 1996-2001, „The Journal of Politics" 67, 2005, nr 2.

Ibenskas R., Sikk A., Patterns of Party Change in Central and Eastern Europe, „Cergu's Working Paper Series” 2016, nr 4.

Internetowy System Aktów Prawnych, www.isap.sejm.gov.pl (dostęp: 31.07.2018).

Janda K., Laws against party switching, defecting or floor-crossing in national parliaments, „The Legal Regulation of Political Parties Working Paper" 2009, nr 2.

Klauziński S., Gdzie poszli ludzie Palikota, „Gazeta Wyborcza” 23.03.2015.

Meyer D.S., Minkoff D.C., Conceptualizing Political Opportunity, „Social Forces” 4, 2004, nr 82. 
Obwieszczenie Państwowej Komisji Wyborczej z dnia 26 września 2001 r. o wynikach wyborów do Sejmu Rzeczypospolitej Polskiej przeprowadzonych w dniu 23 września 2001 r., http://isap.sejm.gov.pl/DetailsSe rvlet?id=WDU20011091186 (dostęp: 5.10.2017).

Obwieszczenie Państwowej Komisji Wyborczej z dnia 27 września 2005 r. o wynikach wyborów do Sejmu Rzeczypospolitej Polskiej przeprowadzonych $w$ dniu 25 września 2005 r., http://isap.sejm.gov.pl/DetailsSe rvlet?id=WDU20051951626 (dostęp: 6.10.2017).

Obwieszczenie Państwowej Komisji Wyborczej z dnia 23 października 2007 r. o wynikach wyborów do Sejmu Rzeczypospolitej Polskiej przeprowadzonych w dniu 21 października 2007 r., http://isap.sejm.gov.pl/Deta ilsServlet?id=WDU20071981438 (dostęp: 7.10.2017).

Obwieszczenie Państwowej Komisji Wyborczej z dnia 11 października 2011 r. o wynikach wyborów do Sejmu Rzeczypospolitej Polskiej przeprowadzonych $w$ dniu 9 października 2011 r., http://isap.sejm.gov.pl/Detail sServlet?id=WDU20112181294 (dostęp: 9.10.2017).

Obwieszczenie Państwowej Komisji Wyborczej z dnia 27 października 2015 r. o wynikach wyborów do Sejmu Rzeczypospolitej Polskiej przeprowadzonych w dniu 25 października 2015 r., http://parlament2015.pkw. gov.pl/akty_prawne/7_Obwieszczenia_PKW (dostęp: 15.10.2017).

Państwowa Komisja Wyborcza, www.pkw.gov.pl (dostęp: 31.07.2018).

Parlament $w$ opinii społeczeństwa - podsumowanie kadencji, Komunikat z badań CBOS BS/104/2005, CBOS, Warszawa 2005.

Political parties and legislative party switching, red. W.B. Heller, C. Mershon, Palgrave Macmillan, New York 2009.

Preferencje partyjne - Komunikaty z badań CBOS z lat 2001-2015, CBOS, Warszawa 2001-2015.

Rational Choice Theory. Advocacy and Critique, red. J.S. Coleman, T.J. Fararo, Sage, Newbury Park 1992.

Raschke C.J., Tils R., Politische Strategie - Eine Grundlage, Springer VS, Wiesbaden 2013.

Sejm Rzeczypospolitej Polskiej, www.sejm.gov.pl (dostęp: 31.07.2018).

Skrzypiński D., Strategie partii politycznych, [w:] Marketing polityczny w teorii i praktyce, red. A.W. Jabłoński, L. Sobkowiak, Wydawnictwo Uniwersytetu Wrocławskiego, Wrocław 2002.

Wojtasik W., Sukces Ruchu Palikota w świetle czynników możliwego sukcesu politycznego (Political Opportunity Structure), „Preferencje Polityczne” 2012, nr 3.

Zuba K., Polska scena polityczna. Ciagłość i zmiana, Wydawnictwo Sejmowe, Warszawa 2012.

\section{Parliamentary party switching in Poland as an element of political strategy}

Keywords: parliamentary party switching, Polish party system, parliamentary parties, party cleavages

\section{Summary}

The article aims to explain the phenomenon of parliamentary party switching in the context of political strategy. Switching parties by legislators during the term is often seen as an opportunistic behavior, focused on obtaining attractive places on electoral party lists. The paper's goals are to determine if the legislators' will to switch parties is correlated with the party public support and, finally, if the deputies truly have better chances of winning reelection if they switch parties. 